\title{
Practical Research on the Teaching Mode of Integration between Industry and Education under the Background of Emerging Engineering Education
}

\author{
Yi Li, Hengyi Yuan* \\ College of Mechanical Engineering, Jilin Engineering Normal University, Changchun, Jilin, 130052, China \\ Supported by JiLin Association For Higher Education (JGJX2020D360)
}

\begin{abstract}
This article analyzes and summarizes the teaching mode of integration of industry and education under the background of emerging engineering education, judges whether the teaching mode of integration of industry and education has advantages in the new work background, and combines professional reforms and the graduation requirements of universities to jointly build a school-enterprise cooperation practice base and major The teaching team cultivates the innovative ability of graduates, guides the graduation design of students, and explores a more comprehensive and in-depth teaching mode of integration between industry and education under the background of emerging engineering education.
\end{abstract}

Keywords: Emerging Engineering Education Construction; Integration between Industry and Education; SchoolEnterprise Cooperation

The development of the world has now entered a new round of technological revolution and industrial transformation. The emergence of technology has made the competition among countries intensified. In the education process of our country, there are higher requirements for the cultivation of innovative scientific and technological talents. Under the background of emerging engineering education, my country is actively exploring the construction model of emerging engineering education. In order to build a strong education country, actively apply new technologies and new industries, and make outstanding contributions to the training of new talents.

\section{School and enterprise jointly formulate training goals and graduation requirements}

\subsection{Formulation of training objectives}

For the formulation of training goals, the validity period needs to be carried out in cooperation. Enterprises need to put forward the requirements of the required talents according to the industry technology development situation and future technology development trends they have mastered, and on this basis, efficiently combine their own professional characteristics and professions Positioning, teacher team affairs and teaching conditions judge the position of graduates in the production practice of the enterprise, and formulate training goals that can meet the current industrial development and conform to future trends, which is conducive to the realization of precise docking between enterprises.

\subsection{Design for graduation requirements}

Under the background of emerging engineering education, the requirements for talents should be combined with the current professional development trend of the industry, with the characteristics of running a school, considering the abilities and qualities of graduates, and jointly design the graduation requirements. To ensure the rationality of

Copyright (c) 2020 Yi Li et al.

doi: $10.18282 /$ le.v9i7.1514

This is an open-access article distributed under the terms of the Creative Commons Attribution Non-Commercial License

(http://creativecommons.org/licenses/by-nc/4.0/), which permits unrestricted non-commercial use, distribution, and reproduction in any medium, provided the original work is properly cited. 
graduation requirements, you can pass a questionnaire Surveys, expert forums and other methods are reviewed by enterprise experts.

\section{School and enterprise jointly optimize the curriculum system and teaching content}

\subsection{The construction of emerging engineering education should pursue the concept of serving the national strategy}

This is the starting point for the construction of emerging engineering education disciplines. In recent years, the country has successively introduced many strategies that are conducive to sustainable development. The construction of emerging engineering education disciplines maintains the same direction among these strategies, and the curriculum system can be adjusted and modified if necessary. , Pay attention to the combination of theory and practice to improve students' professional ability.

\subsection{Emerging engineering education construction should follow the concept of docking industry}

This is the foothold of the construction of emerging engineering education. Under this concept, we will vigorously develop new technologies and promote the docking between education and industry needs. In order to meet the needs of emerging industries, we can combine the opinions of experts, introduce new machinery and equipment, and integrate the Internet New technologies such as information technology and artificial intelligence are integrated into relevant courses. At the same time, based on the development trend of enterprises under the background of the new economy, it will meet the talent needs of future enterprises, pay attention to the cooperation between schools and enterprises, build an education platform integrating production and education, and train students The innovative ability to cultivate highquality emerging engineering education talents in the era of new economic development.

\subsection{The construction of emerging engineering education disciplines should take leading} industry development as a new starting point

In the context of emerging engineering education, the integration model of production and education should fully reflect the concept of leading future development, optimize and adjust the curriculum system and teaching content, conduct professional construction of curriculum teaching, and formulate teaching goals according to industry development trends and industry development needs. Optimize the teaching process to cultivate innovative talents who can lead the development of the industry.

\subsection{Implement the "student-centered" concept and stimulate students' interest in learning}

Under the emerging engineering education concept, more emphasis is placed on the diversification and innovative training of talents. This requires that the education process should be student-centered, respecting the wishes of students, so that they can choose their own development direction, and at the same time, optimize the education of Effect, fully exercise students' thinking and innovation ability. With the help of the Internet platform, an Internet + teaching model is formed, so that students can transform from passive learning to active learning.

\section{School-enterprise joint construction of off-campus practice base}

\subsection{Basic cognitive teaching module}

The main goal of the basic cognition teaching module is to lead students to understand the basic knowledge of the industry, grasp the development trend of industry technology, and make students clarify the constraints of policies and non-technical factors on practice. Through this module, students can have a higher professional ethics, have a better understanding of the basic situation of the industry, and lay a foundation for subsequent practice.

\subsection{Professional skills training module}

The professional skills training module is the foundation for students to invest in practice. At this stage, students need to understand the process flow of each department, master the corresponding technology, clarify the content of 
business practice and professional skills assessment of each department, and deepen the students through training Understanding of theoretical knowledge. This module can greatly improve students' practical ability in a short time, enable students to master professional skills more proficiently, and at the same time deepen students' understanding of the major.

\subsection{Comprehensive practical application module}

The comprehensive practical application module is to allow students to truly participate in enterprise projects, lead students to truly experience the operation of the enterprise, and enable students to apply modern technology to solve corresponding problems by themselves, and to improve students' professional and collaborative capabilities.

\section{The teaching team communicates with each other}

If you want to realize the integration between industry and education under the background of emerging engineering education disciplines, you should first create a team of teachers with high engineering innovation ability. Colleges and universities should continuously optimize the teaching ability of teachers and supervise teachers to continue academic research. At the same time, it is necessary to strengthen the communication between the school teacher team and the enterprise team, and improve the abilities of both through complementary advantages, so that school teachers can make up for the shortcomings of practical ability, and allow enterprise personnel to continuously update theoretical knowledge.

\section{Concluding remarks}

The promulgation of the emerging engineering education series documents fully reflects the country's emphasis on cultivating talents with emerging skills. Under this background, university education should pay more attention to the exploration of teaching models integrating production and education, deep integration with industries and enterprises, and building more efficient new technologies. A platform for training innovative engineering talents to improve the overall quality and professional skills of college students.

\section{References}

1. Gu Chaogang. Briefly on the new mode of integration of production and education in higher vocational colleges[J]. Farm Staff, 2020(22):212.

2. Yu Qin. Exploration of the teaching model of "integration of action and knowledge" under the background of integration of production and education[J]. Modern Vocational Education, 2020(29): 220-221.

3. Zhao Xu, Suo Hao, Wang Dan. Practice research on the teaching mode of integration of production and education under the background of "new engineering"[J]. Navigational Education Research, 2020, 37(01): 10-14. 